\title{
Film Festivalleri \\ Bağlamında Ana Yurdu \\ Filminin Çerçeveleniși \\ Bir Türkiye Metaforu Olarak Ana Yurdu
}

\section{Hasan Akbulut}

Istanbul Üniversitesi Iletișim Fakültesi

https://orcid.org/0000-0003-0465-8355

hasan.akbulut@istanbul.edu.tr, hasan.akbulut@kcl.ac.uk

Öz

Bu makale, Senem Tüzen'in Ana Yurdu (2015) filminin festival gösterimleri bağlamında yazıımıș basın eleștirilerinde, filmin hangi tema ve söylemlerle çerçevelendiğini incelemeyi amaçlamaktadır. Çeșitli film festivallerinde gösterilen ve eleștirmenlerin dikkatini çeken Ana Yurdu, romanını bitirmek için Istanbul'dan anneannesinin köy evine gelen Nesrin'in, annesi ile olan gerilimli ilișkisini konu edinir. Film, olaydan çok karakterlere odaklanması, anlatısal belirsizliği, açık uçlu sonu, geçișli bir anlatıya sahip olması gibi özellikleriyle sanat filmi olarak değerlendirilebilir. Ancak festival gösterimleri ve film eleștirileri de bir filmin sanat filmi olarak tanımlanmasında önemli bir rol oynar. Bu amaçla makalede 12 film eleștirisi tematik olarak analiz edilmiș ve filmin "Türkiye'nin metaforu", "kadın öyküsü" ve "kușak çatıșması" olarak çerçevelendiği saptanmıștır. Elde edilen veriler, sanat filmi ve film festivalleri literatürü çerçevesinde tartıșılmıștır.

Anahtar Kelimeler: Ana Yurdu, film eleștirisi, film festivalleri, filmin çerçeveleniși, sanat filmi.

Makale geliș tarihi: 15.4.2020 - Makale kabul tarihi: 24.8.2020 


\title{
The Framing of the Film
}

\section{Motherland in the Context} of Film Festivals

\section{Motherland as a Metaphor of Turkey}

\author{
Hasan Akbulut \\ istanbul University Faculty of Communication \\ https://orcid.org/0000-0003-0465-8355 \\ hasan.akbulut@istanbul.edu.tr,hasan.akbulut@kcl.ac.uk
}

\section{Abstract}

This article analyses the themes and discourses of how press reviews in the context of festival screenings frame Senem Tüzen's film Motherland (2015). The film focuses on a woman named Nesrin, the protagonist, who travels from Istanbul to her grandmother's village in order to finish her novel, and on Nesrin's tense relationship with her mother. The film has several features that allow it to be characterised as an art film: its focus on characters rather than events, its narrative uncertainty, its open-ended structure, and its transitive narrative. But festival screenings and film criticisms also play an important role in a film's being defined as an art film. In this study, 12 film reviews were analysed thematically. It was found that these framed the film as 'a metaphor of Turkey', a 'woman's story', and 'a generational conflict.' The data obtained are discussed within the framework of the literature on art film and film festivals.

Keywords: Motherland, film criticism, film festivals, framing films, art films.

Received: 15.4.2020 • Accepted: 24.8 .2020 
Bir filmin anlamı ya da anlamları, filmsel metnin kendisiyle sınırlı değildir. Sinema literatürü, filmin anlamlandırılmasında, filmin üretim, dağıtım ve gösterim sürecinin göz önünde bulundurulması gerektiğini vurgulayan çalışmalarla zenginleşmektedir (Staiger 1992; 2000; 2005; Pramaggiore ve Wallis 2011). $\mathrm{Bu}$ literatürün bir kısmını oluşturan alımlama araştırmaları, filmin seyirciler tarafından anlamlandırılmasında onun yapımcılar tarafından tanımlanma biçimine ve medyada yayımlanan film eleştrilerinin önemine dikkat çekerler. Janet Staiger'in belirttiği gibi alımlama araştırmaları, anlayışlı bir eleştirmen tarafından çıkarılacak bir öz olarak anlamı varsaymaz. Bu yüzden alımlama çalışmaları şu soruları sorar: “Bir metnin ne tür anlamları vardır? Kimin için? Hangi durumlarda? Zamanla ne gibi değişiklikler olur? Bu anlamların herhangi bir bilişsel, duygusal, sosyal, politik bir etkisi var mı?" (Staiger, 2005, 2). Staiger'in geliştirdiği biçimiyle "yalnızca medya iletilerinin tüketimi hakkında değil, aynı zamanda onları üretmeye erişim hakkında olan alımlama araştırmaları" $(2005,4)$ anlamların inşasında metnin üretildiği ve tüketildiği tarihsel ve toplumsal bağlamı dikkate alması nedeniyle tarihsel materyalist niteliğe sahiptir. Onun tarihsel materyalist alımlama yaklaşımı, "hayranlar ve eleştirmenler tarafından yapılan değerlendirmeler, haber makaleleri ve oyuncular ve yapım ekibi ile yapılan tanıtım amaçlı görüşmeler gibi filmlerin gösterime girdiği dönemde dolaşımda olan çeşitli tarihsel söylemlerle iliş- 
kili olarak filmlerin anlamlarının çözümlenmesi" şeklinde ele alınmaktadır (Chandler ve Munday 2018, 17). Alımlamayı tarihselleştiren Staiger'in yaklaşımı (1992, 2000, 2005), belirli tarihsel dönemlerdeki olası okuma dizilerine ilişkin bir kavrayış sağlar ve belirli filmler, türler, yönetmenler ya da daha geniş olarak sinema hakkındaki tarihsel, politik ve diğer söylemler ile beklentiler ufkunu incelemeyi içerir (Biltereyst vd. 2012, 694). "Beklenti ufku” türün, okurlarda belli beklentiler oluşturduğu görüşüne dayanır (Jauss 1982, 168). Film festivalleri ile film eleştirileri, seyirci üzerinde bu tür bir etki yaratma gücüne sahiptir. Bu nedenle nasıl anlamlandırıldığını anlamak için önce filmin nasıl etiketlenerek dolaşıma sokulduğunu incelemek gerekmektedir.

Senem Tüzen tarafından yönetilen Ana Yurdu filmi, 2015'te 72. Uluslararası Venedik Film Festivali kapsamında dünya prömiyerini yaptıktan sonra çeşitli ödüller almış ve eleştirmenlerin dikkatini çekmiştir. Ana Yurdu filmine ilişkin tarihsel materyalist bir alımlama araştırmasının parçası olarak yazılan bu araştırma kapsamında filmin, gösterildiği festivallerde ve diğer etkinliklerde nasıl tanıtıldığı, film eleştirmenleri tarafından nasıl çerçevelendiği ve yorumlandığı analiz edilmiştir. ${ }^{1}$ Çerçevelemeyi "dağınık kavramsallaştırma" olarak tanımlayan Entman, bunun temel olarak seçmeyi ve dikkat çekmeyi içerdiğini; çererçevelemenin, "algılanan gerçekliğin bazı yönlerini seçmek ve bunları açıklayıcı bir metin içinde, tarif edilen öğe için ayrıcalıklı bir sorunsal olarak tanımlamayı, nedensel yorumlamayı, ahlaki değerlendirmeyi ve/veya çözüm önerisini teşvik edecek şekilde daha belirgin hale getirmek" olduğunu belirtir (1993, 51-52). Filmlerin festivaller için hazırlanan katalogları ve basında yer alan tanıtım ve eleştirileri de böylesi bir çerçeveleme yapar. Alice Hall bu olguyu, "film eleştirmenleri, filmin bazı yönlerini veya unsurlarını özellikle önemli olarak işaretleyerek izleyicilerin filmleri yorumlama şeklini biçimlendirebilir" sözleriyle ifade eder $(2001,403)$. Popüler ya da akademik olsun, filmler hakkındaki eleştiri yazıları, seyircilerin bir filmi görmeye değer olup olmadıklarına karar vermelerine yardım eder. "Film eleştirileri, bir filmin belirli bir ruh haline veya izleme içeriğine uygun olup olmadığı hakkında ipuçları da sağlar" (Hall 2001, 402-403) ve böylece bir beklenti yapısı üre$\bullet \bullet$

1 Bu makale, TÜBİTAK BİDEB tarafından 2219 Yurt Dışı Doktora Sonrası Araştırma Burs Programı kapsamında desteklenen "The Reception of Turkish Art Films in a Global Context: Cinema Experience of Turkish Immigrants Living in London" başlıklı araştırma çerçevesinde, 12 Ağustos 2019-12 Ağustos 2020 tarihleri arasında misafir araştırmacı olarak bulunduğum University of East London, MIRC Moving Image Research Centre ve University of London, King's College London, Film Studies Bölümü bünyesinde üretilmiştir. Destekleri ve yüreklendirmeleri için Prof. Dr. Valentina Vitali'ye (UEL) ve Prof. Dr. Chris Berry'e (King's College London) teşekkür ederim. 
tir. Hall'ü ve Entman'1 izleyecek olursak $(1993,53)$ filmler hakkında basında çıkan eleştirlerin, seyirciler ve film programcıları için onların filme vereceği tepkiyi etkileme gücüne sahip olduğu ve bu gücün, filme ilişkin seçme ve vurgulama yöntemlerinden kaynaklandığı söylenebilir. Noriega'nın belirttiği üzere, "gösterime giren bir film hakkındaki söylemleri analiz ederek film hakkındaki referans çerçevelerini ve alımlamada içerilmiş söylemleri ayırt edebiliriz" (1990, 35). Böylece film hakkındaki eleştirileri bir metin olarak inceleyerek "medya anlatılarının altında yatan çerçeveleri tanımlayıp açıklayabiliriz" (Entman 1993, 57; Cooper, Pease 2008, 253).

Bu amaçla yola çıkılan makalede veri toplama tekniği olarak doküman incelemesi kullanılmıştır. Mayring'e göre dökümanlar, özel anlamları olan belgeler, istatistikler, filmler, sanat eserleri, binalar gibi insan davranışının açıklamasına yardımcı olan her türlü kaynaktır (2011, 51-53). Bu çalışmada ise Ana Yurdu hakkında film festivallerinde ve basında yer alan İngilizce yayımlanmış 12 adet tanıtım yazısı ve eleştiri doküman olarak kullanılmıştır. Bu tanıtm ve eleştirilerin bir kısmı filmin web sayfasında yayımlanmıştır. Diğer yazılara ise online platformlardan filmin özgün ve İngilizce ismiyle yapılan aramalardan erişilmiştir. Makalede öncelikli olarak bir filmin etiketlemesinde filmin metinsel özellikleri kadar gösterildiği bağlam da önemli olduğu için sanat filmleri ve film festivalleri arasındaki ilişki kuramsal boyutlarıyla özetlenmiş, ardından Ana Yurdu filmine ilişkin eleştiriler tematik olarak analiz edilmiştir. "Metinlerin içeriğini ve anlamını ya da yapılarını ve söylemini yakından inceleyen bir veri analizi yöntemi olan metin analizi" (Lockyer 2008, 865), medya içeriklerinde anlamın nasıl inşa edildiğini ortaya koymaya yarar ve onlarda örtülü olan gündemi, farklı noktaları, bakış açılarını ve geleneksel söylemsel özelliklerini tanımlamayı sağlar (Green 2002, 225). Araştırmada Ana Yurdu filmi hakkında yazılan eleştiriler birer metin olarak alınmış ve tematik olarak analiz edilerek filmin hangi kavram, tema ve söylemlerle çerçevelendiği tartışılmıştır. Ana Yurdu filminin festivaller ve uluslararası gösterimler bağlamında basında nasıl çerçevelendiğini ortaya koymayı amaçlayan bu makalede, böylece filmin seyirciler tarafından alımlanmasına ilişkin tarihsel ve bağlamsal etmenler serimlenmiş olacaktır.

\section{Sanat filmleri tanımlamasında film festivalleri}

Metinsel olarak bakıldığında sanat filmleri, diğerlerinden ayrılan anlatısal ve görsel biçemleriyle tanımlanabilir bir türdür. Öneğin Charles William Siska, modernist kavramların (öznellik, bakış açısı, düşünümsellik ve açık doku) ve Godard sineması üzerinden onların türevlerinin (geçişsiz anlatı, yabancılaş- 
ma, öne çıkma, çoklu anlatım, metinlerarasılık ve açık uç), sanat filmlerini bir tür olarak tanımlamada bir çerçeve sağladığını belirtir (1980, 3). Sanat filmleri, kolay anlaşılır, tek bir öyküye odaklanan, olayların nedensellik ilişkisine göre birbirine eklendiği, seyirciyi özdeşlemeye yönelten ve bitiş duygusu veren sonlu klâsik anlatı sinemasından farklı özelliklere sahiptir. Andrew Butler'a göre sanat sineması "ağırlıklı olarak Hollywood dışında çekilen, salt para kazanma kaygısından öte, kişisel söylemler olarak çekilmeye çalışılan ve avantgard olarak yorumlanabilen filmleri tanımlamak için kullanılan bir terimdir" (2005, 138). Marilyn Fabe de sanat sineması denildiğinde akla Avrupa ve Japonya'dan ticari olmayan filmler yapan, filmlerinde yaratıcı özgürlük sorunlarıyla uğraşan Bergman, Bresson, Ozu ve Murnau gibi yönetmenlerin geldiğini belirtir $(2004,121)$. Daha tanımlayıcı çalışmasında Peter Wollen, sanat filmlerini değerlendirmede çağdaş anlatı kavramını kullanarak Fransız yönetmen Jean-Luc Godard'in Vent d'est (Doğu Rüzgârı, 1970) filmi ekseninde bu özellikleri şöyle sıralar: Geçişli anlatıya karşı geçişsiz anlatı; özdeşleşmeye karşı yabancılaşma; saydamlığa karşı öne çıkma; tek anlatıma karşı çoklu anlatım; kapalı sona karşı açık uçlu son; hoşlanmaya karşı rahatsız olma; kurmacaya karşı gerçek (Wollen 2010, 113). Sanat filmi, modern estetiğin ayrımlarından biri olan estetik öz-bilinçlilik ya da öz-düşünümsellik (self-reflexiveness) niteliğine sahiptir (Öztürk 2000, 41- 42) ve kendi gerçekliğini bilinçli bir yorum ya da oyun olarak açığa vurur (Lunn 1995, 48). David Bordwell'ın biçimci yaklaşımında ise sanat filminin, karakter üzerine odaklamasıyla, neden-sonuç ilişkisinin zayıflamasıyla, gerçekçilik ile yazarsıl (authorial) anlatımcılık vurgusuyla belirlendiği görülür. Bordwell'e göre sanat sineması, belirsizlik aracını kullanarak sorunu sofistike bir şekilde çözmeye çalışır. Bu nedenle de belirli bir okuma yöntem gerektirir (Bordwell 2010, 78). Sanat filmlerinin biçem ve izlek olarak bir kip biçiminde tanımlanabileceğini iddia eden Bordwell (2010, 72-73), aynı zamanda bu kipin ne gibi okuma stratejisi gerektirdiğine ve sinemasal söylem düzeyinde ne gibi çelişkiler bulunduğuna da bakmak gerektiğini belirtir ve hem nesnel hem de öznel gerçeğe verilen önemle birlikte auteurün de bir yapı olarak filmin içinde öne çıkarılmasını, sanat sinemasının temel kipleri olarak görür. Film eleştirmenleri ve film endüstrisi, filmi, bir auteurün filmi olarak etiketlerken seyirciler de onun filmlerinde tekrarlanan bazı anlatısal ve görsel kodlar arama eğilimine girer. Böylece sanat filmi, “kendini ifade eden bir bireyin eseri olarak okunur" (Bordwell 2010, 77).

Tarihsel süreç içinde kapsadığı anlam farklı olsa da günümüzde auteur, anlatısı ve anlatım biçimi, üslubu, filmlere yerleştirdiği kişisel anlamı, film üretim, dağıtım ve gösterim tarzındaki farklılıklarla tanımlanmakta ve 
çoğunlukla sanat filmleri yapan yönetmenleri işaret etmektedir. Thomas Elsaesser de auteur sinemasının genellikle sanat sinemasıyla ele ele gittiğini söyler ve onun biçimsel, üslupsal ve anlatıbilimsel ayrımlarına ek olarak kurumsal bağlamını vurgular. Yazara göre sanat filmleri, normalde benzer bir işlevi yerine getiren "sanat ve deneme" sinemaları ("art et essay" cinemas) ya da "Programmkinos"lar, sinematekler olarak tanımlanan kita Avrupası'nda olduğundan çok, ABD'de ve İngiltere'de "sanat evleri"nde (art house) gösterilen filmlerden oluşmuştur (Elsaesser 2005, 23). Elsaesser "ayrı bir biçimsel estetik anlatım tarzı olarak sanat sinemasının aynı zamanda ya hükümetlerin desteklediği ya da bağımsız biçimde programlanmış, böylece potansiyel olarak ana akım 'klâsiklerin' bir retrospektifini ya da yeniden canlandırılmasını içeren kurumsal-pragmatik bir kategori" $(2005,16)$ olduğunu belirterek sanat sineması tanımlamasında film endüstrisinin rolüne işaret eder. Zira Amerikan dağıtım şirketlerince sanat evlerinde gösterildiğinde, Avrupa'da üretilmiş filmler, sanat sineması olarak tanımlanmıştır. Benzer biçimde Deslandes ve Maxient de Nuri Bilge Ceylan sinemasında fark edilebilir kimi özelliklerin, film finansmanı ile ilgili olabileceği konusunda bir tartışma açarlar (2011). Böylelikle sanat sinemasının endüstriyel, türsel ve estetik kategorilerle birlikte tanımlanabilceği (Galt ve Schoonover 2010, 3) ve belirleyici özelliklerinin, metinsel olduğu kadar kurumsal da olduğu görülür. Nitekim Steve Neale'in sanat sineması kavrayışı da metinsel özellikler kadar kurumsal nitelikleri vurgular. Neale'a göre sanat sineması, Avrupa ülkelerinin hem yerel pazarlardaki Amerikan hâkimiyetine karşı çıkma hem de kendilerine ait bir film edüstrisi ve film kültürü geliştirmesine yardım etme işlevini yerine getirir $(2010,83)$. Bu farklılaştırma çabası içinde sanat filmleri, Neal'ın saptadığı gibi bir yandan ulusal kültürel ve sinemasal geleneklere yaslanır, diğer yandan da uluslararası dağıtım ve gösterim için üretilir. Bu nedenle "filmlerin kendileri de belli ulusal kimliklerin inşasına ve yeniden inşasına katılırlar. Bu filmleri işaretleyen ulusal belirtiler ise onları Hollywood'da yapılan filmlerden farklılaştırmaya hizmet eder" (Neale 2010, 107-108). Bu süreçte film gösterim ve dağıtım pratikleri de önemli roller üstlenir.

Filmlerin gösterildikleri ve dolaşıma sokuldukları bağlam da onların sanat filmleri olarak etiketlenmesinde etkilidir ve festivaller, sanatevleri, film eleştirmenleri ve yapım şirketleri de bu süreçte etkin aktör konumundadır. Dina Iordanova, bu nedenle festival incelemelerinin, ulusal sinemaların veya metinlerin bir araya gelmesinden ziyade, ulusötesi ve sosyal boyutlara sahip önemli bir sanat formu olarak filmin incelenmesinde anahtar rolü olduğunu söyler (2016: XII). Marijke de Valck ise festival programlama pratiklerinin 
festival filmlerini anlamaya ve üç başlık altında çerçevelemeye (ulusal sinema, auteur sinema ve sanat sineması) katkıda bulunduğunu, bu sinemaları tartışmak için eleştirel bir sözlükçe (auteur ve Yeni Dalga gibi) sağladığını belirtir. Yazara göre gerçekte film festivalleri uluslararası, kozmopolitik bir sanat sinemasının yaratılmasında ve sürdürülmesinde büyük bir rol oynar görünür: "Yeni yetenekler tespit edildiğinde, onlar; uluslararası fonlar, pazarlar, eğitim programları ve yapımcılar dünyasına girer ve bu yönetmenlerin filmleri, yıllar geçtikçe sonuçta daha az ulusal olarak ayırt edici olmaya başlar" (de Valck 2012, 35-36). Ana Yurdu da bazı destekler ve fonlarla de Valck'ın tanımladığ şsekilde üretilmiştir. Dudley Andrew festivaller ve eleştirmenlerin yer aldığı bu bağlamın artık küresel olduğunu, bu küresel ağın yeni dağıtım kanalları, formatları ve kabul etme kültürü sağladığını belirtir (2010, x). Bu nedenle Galt ve Schoonover sanat filmlerinin, başından beri estetik ile jeopolitika, diğer bir deyişle sinema ve dünya arasındaki ilişkiyi güçlendirdiğini, küreselleşme, dünya kültürü ve sinemanın ulus-ötesi akış ekonomisinin, film biçiminin yörüngeleriyle kesişebileceğine ilişkin çağdaş sorunları anlamak için eleştirel bir kategori olduğunu ifade ederler (2010, 3). Yazarlara göre sanat filmleri "çoğunlukla yalnızca sanat evlerinde ya da festivallerde gösterilen filmlerdir ve varoluşları, belirli eleştirmenler, film programcıları ve dağıtım biçimlerine bağlıdır" (Galt ve Schooner 2010, 7). Bu nedenle yazarlar yerelle çelişik bir ilişki kurmuş olan sanat filmlerinin uluslararası bir kategori ve genellikle yabancı filmler için bir kod olduğunu vurgulayarak, bazı ülkeler için bir filmi sanat sineması yapan şeyin, bu uluslararası dolaşım olduğunu belirtirler $(2010,7)$. Öyleyse denilebilir ki sanat sineması, yerel ve ulusal olan özelliklerle ilişkili olsa da üretim ve gösterim dinamikleri nedeniyle bu tür yerel, ulusal, türsel sınırları aşan, saf olmayan bir formdur. Sanat sineması, Peter Lev'in vurguladığı gibi hem uluslararası bir fenomendir hem de yerel gösterim tarihine bağlıdır $(1993,6)$. Sinema endüstrisinin bu süreçteki rolünün günümüzde de etkili biçimde devam ettiği açıktır. Öyle ki Elsaesser'in vurguladığı gibi günümüzde film ticareti ve kültürel sermaye alışverişi küreselleşmiş, film festivalleri döngüsü içinde sanat sineması ve bağımsız sektör hızla ulusal sınırların ötesine uzanmıştır $(2005,18)$. Uluslararası film festivalleri bir ulus-ötesi söylem retoriği ile kurulmuş olsa da Roy Armes, "gerçekte festivalin bir tür süzgeç gibi davrandığını" ve yalnızca belirli Batılı ölçütlere uyan ve üçüncü dünya sinemasına dair görüşümüzü tamamen bozan işlerden nasıl yararlanılabileceğine işaret eder: “Üçüncü dünyanın popüler ticari başarıları, uluslararası dağıtım için kasıtlı olarak ısmarlanmadıkça, ödül dahi almış olsa bir gösterim elde etme olasılıkları çok düşüktür" (akt. Harris 2008, 
79). Bu küresel akış içinde yönetmenlerin özgün tematik ve görsel ortaklıkları ile fark edilebilir bir stil repertuarından söz etmek de mümkün hale gelmiştir. Elsaesser'in belirttiği gibi kısmen yeni film teknolojileri tarafından belirlenen ve sinefil bir sinema tarihi referansiyla dolu olan bu stil repertuvarı, seyircilerin onu uluslararası festival filmi olarak adlandırmasını sağlayacak biçimde tanıdıktır (2005, 18). Yönetmenlerin "uluslararası festival filmi” kavrayışını pekiştirecek biçimde seyircileriyle paylaştığı sinema tarihine referanslar içeren stil repertuarı, festivaller aracılığıyla tanınır hale gelir. Festivaller çerçevesinde yazılan film eleştirileri ise filmlere ilişkin bağlamsal söylemlerin inşasında, dolayısıyla seyircilerin filmleri alımlamasında, etkili olur. Ancak bu inşa, filmin kendisinin nasıl ve hangi kavramlarla dolaşıma sokulduğu ile başlar.

\section{Filmin kendisini sunușu: Ana Yurdu kültürel tanınmayı talep ediyor}

Ana Yurdu, üretim ve metinsel özellikleri dikkate alındığında sanat filmi olarak nitelenebilir. Az sayıda oyuncuyla küçük bir ekiple üretilen film, Tüzen'e göre "kadın kimlikleriyle ilgilenir ve anne-kız ilişkisi aracılığıyla kadın olmanın ne demek olduğunu sorgular" (Beyer, 2016). Filmde evrensel anne-kız ilişkisi ya da çatışması, bu ilişkiyi yönlendiren toplumsal, kültürel, dinsel ve gündelik pratikler içinde sunulur. Film başladığında öykü çoktan başlamıştır. Yönetmen, film kişileri ile zaman-mekânı, olay örgüsü ile birlikte sunar. Bir traktörün romörkunda genç bir kadın görürüz. Filmin ilerleyen dakikalarında bu kadının eşinden boşanmış, İstanbul'da yaşayan, eğitimli biri olduğunu ve yazmakta olduğu romanını tamamlamak için anneannesinin ölümünden sonra onun köydeki evine dönen Nesrin (Esra Bezen Bilgin) olduğunu öğreniriz. Nesrin, temizleyip havalandırdığı evi yazmak için hazır hale getirdiğinde, annesi Halise, davetsiz biçimde çıkagelir. Emekli bir öğretmen olan Halise (Nihal Koldaş), bitirdiği evliliği, giyim kuşamı ve davranışları konusunda sürekli Nesrin'i eleştirir ve ona nasihatler verir. Nesrin romanını yazabilmek için yalnızlığa ihtiyaç duyduğunu söylese de Halise onu dinlemez ve Nesrin'in hayatına ilişkin özel bilgileri komşu kadınlarla paylaşır. Nesrin'in köylü kadınlarca ötekileştirilmiş Emine’yle (Fatma Kısa) görüşmeye devam etmesi, hakkındaki dedikoduları alevlendirir. Bozulan araba bir türlü tamir edilmez, Nesrin romanını yazamaz. Anne-kız arasındaki çatışma büyümeye başlar ve Halise, Nesrin'in davranışları, düşünceleri ve duyguları üzerinde bir tahakküm kurmaya çalışır; onu namaz kılmaya, dua etmeye zorlar. Sonunda Nesrin, akıl sağlığı yerinde görünmeyen köylü bir erkekle cinsel bir deneyim yaşar, ancak film açık sonla biter. 
Anlatısal belirsizliği, açık sonu, karaktere ve sanatsal üretim sürecine odaklanması, yani düşünümsel bir pratik içermesi nedenleriyle Ana Yurdu, sanat filminin türsel özelliklerini taşır. Az sayıda karakterin yer aldığı filmde temel karakter Nesrin'dir. Nesrin, Chatman'ın kavramsallaştırdığı gibi "çatışan, çelişen farklı karakteristik özelliklere sahip, çelişkili”, "boşlukları olan”, üzerinde "derin düşüncelere" sevk eden, "akılda kalıcı", "bulguları belirsiz”, "açık uçlu" bir karakterdir (2008, 123-24). Onun davranışlarının nedenleri anlaşılmadığı gibi sonuçları da "akılcı" görünmez. Halise ise Nesrin'in davranışlarındaki kararsızlığı ve farklılığı görünür kılan bir öteki karakterdir. O, ilk bakışta Nesrin üzerinde baskı uygulayan bir fail gibi görünür ancak o da zamanında bu baskıların hedefi olmuştur. Film, Türkiye' de bağımsız bir birey ya da kadın olmayı belirleyen siyasal, dinsel, toplumsal ve ideolojik kodlar üzerine farklı okumalara açıktır.

Ana Yurdu, taşraya dönerek kendisiyle ve geçmişiyle hesaplaşan erkek merkezli karakterin anlatıldığı Nuri Bilge Ceylan'ın, Semih Kaplanoğlu'nun filmlerine de benzer. Ancak bu filmde köye dönen karakter bir erkek değil, kadındır. Nuri Bilge Ceylan'ın, taşraya dönerek film çekmek isteyen karakterleri gibi Nesrin de romanını yazmak için köye döner. Onun dönüşünün kısa sürede filmini çekmek için alınmış pratik ve pragmatik bir karar olduğunu fark etsek bile son dönem Türkiye sinemasında taşraya dönen entelektüel karakter özelliğiyle Ana Yurdu, sanat sineması geleneğine bağlanır.

İnsanlığa, kimliğe, kadınlığa dair kavrayışları sorgulama potansiyeli taŞıyan Ana Yurdu anlatısal özellikleri ile minimal ve anlatımcı mizanseni, karakterleri yarı karanlıkta bırakan aydınlatma tekniği ve anne-kız arasındaki uzaklığı ifade eden çerçevelemeleri, soğuk renkleri gibi biçimsel nitelikleriyle sanat filmidir. Ancak filme ilişkin eleştiriler, filmin özelliklerinden bazılarını seçer, ayırır ve çerçeveler. Film, daha yapım öncesi destekleriyle uluslararası sanat sineması camiasının dikkatini çekmiştir. Filmin web sayfasının başında yer alan şu ifadeler, onun bir festivalde gösterilebilmesi için gerekli olan süreçlerden geçtiğini duyurur:

Ana Yurdu, üretim ve yapım süreçleri için T.C Kültür Bakanlığı' ndan destek almış bir uzun metraj filmdir. Henüz yapım sürecindeyken, hem Selanik eş-yapım pazarında "En İyi Proje”, hem de İstanbul'da Köprüde Buluşmalar ödülünü almıştır. Film aynı zamanda !F-Sundance ScreenWriter's Lab'da da temsil edilmiştir (https://anayurdu.com/indextr.html, 2019). 
Filmin üretim sürecinde aldığı yapım destekleri hakkında bilgi veren bu açıklama, Andrew'ın ifade ettiği gibi filmin, küresel ağın yeni dağıtım kanallarına, festival döngüsüne girmesi için bir çağrı niteliğindedir ve geçirdiği üretim aşamalarıyla kabul edilmeyi talep eder (2010). Bir filmin statüsünün tanımlanmasında festivaller ve eleştirmenler önemli bir işlevi yerine getirirler. Allen ve Lincoln film alanında bu süreçte profesyonel, eleştirel ve popüler olmak üzere üç tür kültürel tanınma olduğunu belirtirler. Film festivalleri ve ödüller, profesyonel tanınma sürecinde başat aktördür. Yazarlara göre "profesyonel tanınma, sanatçılara ve eserlerine diğer sanatçılar tarafından verilir ve film endüstrisindeki en önemli mesleki tanınma biçimlerinden biri, filmin Akademi Ödülü'ne aday gösterilmesidir" (Allen ve Lincoln, 2004, 879). “Eleştirel tanınma, eleştirmenler ve akademisyenler tarafından atfedilmekteyken popüler tanınma en iyi biçimde filmin seyirci sayısı ve kazandığı gişe hasılatıyla" değerlendirilir (Allen ve Lincoln, 2004, 879-80). Filmlerin eleştirel tanınması, medyada ve akademik dünyadaki film eleştirileri aracılığılyla işler ve Ana Yurdu filminin web sayfasında yer alan bilgiler, filmin hem profesyonel hem de kültürel saygınlığı talep ettiğine işaret eder. Popüler tanınma ise çoğu sanat filmi için olduğu gibi Ana Yurdu için de geçerli bir tanınma yolu olarak görülemez. Zira Boxoffice Türkiye verilerine göre film, Türkiye'de vizyona girdiği 25 Aralık 2015 tarihinden itibaren 15 haftada 6.018 seyirciye ulaşmış ve ancak 54.394,20 TL hasılat (2020) yapabilmiştir. ${ }^{2}$ Bu nedenle Ana Yurdu'nun gösterim sürecinin festivaller ve özel gösterimler biçiminde gerçekleştiği, bu biçimin ise festivaller ve eleştirmenleri aktör olarak öne çıkaran profesyonel ve eleştirel bir tanınma talebini harekete geçirdiği görülür.

\section{Geleneksel/modern arasında bir araf olarak Ana Yurdu}

Dünya prömiyerini 72. Venedik Uluslararası Film Festivali kapsamında Uluslararası Film Eleştirmenleri Haftası (International Critics' Week Award) (212 Eylül 2015) $)^{3}$ bölümünde yapan Ana Yurdu, 31. Varşova Uluslararası Film Festivali'nde (9-18 Ekim 2015) Uluslararası Sinema Yazarları Federasyonu FIPRESCI ve NETPAC; Asya Pasifik Film Ödülleri Yarışması'nda (2015) “En İyi Senaryo"; 35. İstanbul Uluslararası Film Festivali'nde (2016) Ulusal Yarışmada FIPRESCI; 16. Tiflis Uluslararası Film Festivali'nde (2015) Altın Promet-

2 Film, Türkiye'de iki kez gösterime girer. Bunların ilki olan 25-31 Aralık 2015 ile 19-25 Şubat 2016 tarihleri arasında film, birer sinema salonunda gösterilir ve sadece 194 kişi tarafından izlenir. Mayıs-Haziran 2016 arasında ikinci kez gösterildiğinde ise daha çok seyirciye ulaşır (Boxoffice Türkiye 2020).

3 Aynı yıl festivale katılan Mustang (Deniz Gamze Ergüven, 2015), Lux Price ödülünü almıştır. 
heus "En İyi Film" ödüllerini (Golden Prometheus Best Film) almış; Sinema Yazarları Derneği (SIYYAD) tarafından 49. düzenlenen SİYAD (2017) ödülleri de dâhil olmak üzere toplam 20 ödül kazanmıştır. ${ }^{4}$

Gösterildiği uluslararası festivaller çerçevesinde Ana Yurdu hakkında çeşitli eleştiriler yayımlanmıştır. Bu makale çerçevesinde incelenen film eleştirilerinin, çoğunlukla festivallerin web sayfalarında, Film Eleştirmenleri Birliği FIPRESCI'nin ve Cineeuropa' $n^{5}{ }^{5}$ yayın organlarında yayımlandığı, dolay1sıyla filmlerle daha profesyonel biçimde ilgilenen eleştirmenleri, seyircileri ve akademisyenleri hedeflediği görülür. Bu eleştiriler, Prince'ın tanımladığı anlamda "daha uzun bir biçime sahip, daha az doğrudan tüketici odaklı olan ve filmi, tarihsel veya kültürel bir bağlamda konumlandırmaya daha fazla önem veren dergi tabanlı yapıdadır" $(1997,321)$ ve profesyonel eleştirmenler tarafından yazılmıştır.

Ana Yurdu'nun festival gösterimleri bağlamında yayımlanmış eleştirilerinde ${ }^{6}$ filmin "günümüz Türkiyesi'nin bir metaforu", "geleneksel toplum ile bireyin çatışması" (Suárez 2015) ve "çarpıcı, cesur, yıkıcı bir kadın öyküsü" (Landesman 2015) gibi başlıklarla etiketlendiği görülür. Venedik Uluslararası Film Festivali için Cineeuropa'da yayımlanmış yazısında Gonzalo Suárez, Ana Yurdu filmini "geleneksel toplum ile modern bireyin karşılaştığı bir film olarak çerçeveler. Suárez, orijinal bulmadığı öyküsüne karşın, filmde gerilimi artırmak için gerekli bileşenlerin ikna edici biçimde kurulduğunu, yönetmenin evdeki kapıları ve odalar arasındaki sınırları kullanarak Nesrin'i nefessiz bırakan dar ve kapalı ortamları bilinçli biçimde oluşturduğunu belirtir (2015). Konunun özgün bulunmayışı, benzer temalı çok sayıda filmin festivallerde

\section{$\cdots$}

4 Bunlara ek olarak filmin aldığı ulusal ödüller şöyledir: 22. Adana Altın Koza Film Şenliği 2015: En İyi Senaryo, En İyi Görüntü Yönetmeni, En İyi Oyuncu, SİYAD En İyi Film / FilmYön En İyi Yönetmen.

27. Ankara Uluslararası Film Festivali 2016: En İyi Film, SİYAD En İyi Görüntü Yönetmeni, En İyi Yönetmen, En İyi Kurgu, En İyi Senaryo.

49. SİYD ödülleri 2017: En İyi Film, En İyi Senaryo, En İyi Yönetmen, En İyi Kadın Oyuncu, En İyi Kurgu.

5 Web sayfasında Cineeuropa hakkında şunlar yazmaktadır: "Cineuropa dört dilde sinema ve görsel-işitsel amaçlı yayın yapmayı amaçlayan ilk Avrupa portalıdır. Cineuropa, günlük haberler, röportajlar, veri tabanları, görsel-işitsel endüstri üzerine derinlemesine araştırmalar yaparak Avrupa film endüstrisini dünya çapında tanıtmayı hedeflemektedir" (2019).

6 Bu eleştirilerden Landesman ve Pellegrini'ye ait olan yazılar, Ana Yurdu filminin web sayfasında (http:/ / anayurdu.com/index.html) Türkçe ve İngilizce olarak yayımlanmıştır. Diğer eleştiriler ise İngilizceden tarafımca çevrilmiştir. 
gösterildiğini ve belki de bu tür bir temanın, festival filmi olarak gösterilmesi için yeterli bir koşul olmadığını düşündürür. Suárez, filmi özgün kılan şeyin ise Nesrin'i kapı aralıklarına, pencerelere sıkıştıran kuşatıcı çerçevelemeler, dar alanlar ve karanlık atmosfer gibi konuyu işleme biçimi olduğunu vurgulayarak karakterler arasındaki gerilme, özellikle Nesrin'in annesine yönelik çelişik duygularına odaklanır (2015). Suárez'in, anne ve kız arasındaki gerilimi, birey/toplum, gelenek/modernite karşıtlıkları aracılığıyla günümüz Türkiyesi'nin bir temsili olarak görmesi ise oldukça dikkat çekicidir:

Bu şekilde, sevgi ve şefkat ışıltılarını korurken iki farklı dünya ve iki farklı zaman dilimi arasında bölünmüş, belki de günümüz Türkiyesi'nde özellikle hassas bir sorunun temsilcisi olan iki farklı kaçış yolunu temsil eden iki karakter arasında dayanılmaz bir birlikte yaşama dinamiği oluşturulmuştur. Bir yandan anne, kendi çevresini ve kasabanın toplumsal ve dini çevresinin bir öğesi olduğunu bilir, -sorunları çözmek için ritüelleri ve geleneklerin kapısını çalar ve kadın komşularıyla iyi geçinir. Öte yandan kızı, aynı çevrede kendisini boğuluyormuş gibi hisseder- kendini savunmaya çalışır ama yalnızca yazar olma hayaliyle değil, yerli halk tarafından sürgün edilmiş günahkâr serserilerinden bir arkadaş bulur ve kaçmayı, çatışmaları çözmenin tek yolu olarak görür. Bununla birlikte, cemaatçilik ve modernite arasındaki kaçınılmaz çatışmadan kaçmanın mümkün bir yolu yoktur. Nereye gidebilir? (Suárez, 2015).

Karakterleri Batılı/Doğulu, modern/geleneksel, ilerici / geride kalmış, birey/cemaat gibi ikili karşıtlıkları çağrıştıracak biçimde kuran Suárez'in yorumunda Nesrin ile Halise arasındaki farklılığın; toplumsal, kültürel ve tarihsel olduğu kadar duygusal olarak da inşa edildiği fark edilir. Öncelikle iki karakterin farklı dünyalara ve zamanlara ait olarak betimlenmeleri, onları bir araya getirilemez ve uzlaşılmaz kılar. Onların farklı dünyalardan olması, mekânsal uzaklıktan öte giyim kuşamları, konuşma dilleri, gündelik hayat pratikleri, beğenileri, inançları, değerleri ve yaşam biçimleri ile arasındaki uzaklığı imler. Yazıda her iki karakterin de kendi habituslarına göre davrandıkları ima edilir. Örneğin Halise, yaşadığı muhafazakâr çevreyi ve onun kurallarını iyi bilir ve köylü kadınlarla işbirliği yaparken Nesrin de kendisi gibi aynı cemaatin dışına sürülmüş bir köylü kadın (Emine) ile arkadaşlık kurar; biri baskı yapmak, diğeri baskıya direnmek için ötekileştirilmiş iki kadındır. Farklı zamanlara ait oldukları tanımlaması ise karakterlerde birini tarihsel olarak geride, diğerini ileride, bir başka deyişle geri kalmış ve gelişmiş olarak nitelemeye götürür. Elbette bu zamansal ve mekânsal farklılık nedeniyle onların uzlaşmaz kategoriler olduğu düşünülür. Bu nedenle Suárez'in yorumlamasinda Ana Yurdu, klostrofobik atmosferiyle günümüz Türkiyesi'nin bir temsili 
olarak birey ile toplum, gelenek ile modernite arasında karşıtlığın bir şimdiki ana sabitlenmiş olur. Nesrin ve Halise de ikiliklerin karşıt uçlarında yer alan karakterler olarak bu sabitliğe, değişmezliğe hapsedilmiş olarak değerlendirilirler. Ne var ki iki karakter tarihsel ve kültürel olarak bölünmüş olsa da yazar, onların bir yanda sevgi-şefkat duyguları, diğer yanda da acıtıcı sözler ve keskin öfkeleriyle yaşamaya mecbur olduklarının altını çizer. Böylece eleştirmen için filmin, bir araya getirilmez tarihsel ve kültürel "yarık" ın bir arada yaşama mecburiyeti nedeniyle vurucu olduğu anlaşılır. Suárez "tutucu ve bask1c1 toplum tarafından kuşatılmış kadın için gerçek bir kaçışın imkânsızlığını belirtir; kültürel, toplumsal ve düşünsel bölünmüşlüğü ile çatışan tarafların bir arada yaşamaya mecbur olduğunu" söyler (2015). Yazıda Türkiye bölünmüşlük, modernlik, gelenek, kapalılık gibi sözcükler aracılığıyla kodlanarak rasyonel, duygusal olarak dengeli, seküler Batı'ya karşı, rasyonel olan ile irrasyonel olanın, dengeli duygular ile dengesiz duygusallığın, geleneksel olan ile modern olanın çatıştığı bir çelişkin toplum olarak inşa edir.

Filmi, Doğulu bir toplumun temsili olarak gören eleştirmenlerden biri de Luca Pellegrini'dir. Pellegrini, Venedik Film Eleştirmenleri Haftası için kaleme aldığı yazısına Nesrin'in döndüğü köyünün yalıtılmışlığını betimleyerek başlar:

Başkentin gençlerle dolu kalabalık caddelerinde değil, Anadolu'nun boş kaldırımlı, yıkık dökük evli ücra bir kasabasındayız. Burada acının ve anıların bekçileri olan kadınlar konuşur, bekler, dua eder ve yaşlanır. Nesrin bir gece "anaların yurdu" olan bu kasabaya varır. Burası aynı zamanda onun; kinle, kaybolmuş beklentilerle, geride bırakılmış hayatlar ve aşklarla dolu, geleceğe aç ve sürekli beklentide olan Türkiyesi'nde kaybolmuş olan "Ana Yurdu"nun bir yansımasıdır (Pellegrini 2015).

Pellegrini henüz yazısının başlangıcında Türkiye'yi, kalabalık caddeli büyük kentlerine karşı "yıkık dökük evleriyle ücra bir Anadolu kasabası" olarak bölünmüş haliyle tanımlar ve bu ıssız yerleri, kadınlarla eşitler. Kadınlar, mutlulukla ve umutla değil, acı ve anılarla yüklenmişlerdir ve Anadolu, "anaların yurduna" dönüşmüştür yazıda. Ana yurdu, bu tanımlamaya göre ilksel vatandır. Terk edilmişlik, 1ssızlık ve melankoli çağrışımlarıyla geri dönülen bu topraklar, yazar tarafından geçmiş ile gelecek, terkedilmişlik ile umut ve bekleyiş arasında bölünmüş Türkiye' nin bir metaforu olarak çizilir. Pellegrini, bu ülkeyi aynı coğrafya ve benzer insanlarla Nuri Bilge Ceylan'ın Cannes ödüllü Kış Uykusu (2014) filminden tanıdığını söyler. Eleştirmenin bu cümlede kullandığı “biz” dili, Batılı seyirciler ve okurları imler ve Ceylan'ın 
2008 yılında Cannes Film Festivali'nde Üç Maymun (2008) filmiyle "En İyi Yönetmen” ödülünü alırken söylediği, "Bu ödülü tutkuyla sevdiğim yalnız ve güzel ülkeme armağan ediyorum" cümlesini anımsatır.

Pellegrini'nin eleştirisinde Nesrin'in tanımlanma biçimi de betimlediği çelişik Türkiye ile uyumlu görünür. Ona göre az konuşan ve gözleri sürekli dalan yaralı bir kadın olan Nesrin' in hayatı da filmde biz seyircilerin göremediği dağlar gibi "varoluşun dengesiz kenarları arasında bir limbo" dur (Pellegrini, 2015). "İstenmeyen veya unutulmuş şey" veya "kimsenin gönderildiği yer veya içinde bulunduğu durum; zindan, hapishane” (Redhouse Sözlüğü 1997, 571-72) anlamıyla cehennem ve arafı çağrıştıran limbo sözcüğü, yalnızca Nesrin' in hayatını değil, günümüz Türkiyesi'ni niteler. Batı ile Doğu, modern ile gelenek, kent ile köy, gelecek ile geçmiş arasında salınan Türkiye için araf, uygun bir tanımlamadır. Ev, Türkiye' nin bir metaforu olarak yalnızca şimdinin kaygılarını, geleceğe dönük umutları değil, aynı zamanda geçmişin acılarını kapsar. Hatta Pellegrini, ailenin görünmeyen üyelerinin varlığının da sürekli yapılan temizlik ediminde olduğu gibi hissedildiğini belirtir. Anneanne ölmüştür, ama onun ruhu evin her yanına sinmiştir. Yazara göre film, "şehirli 'medeniyet'ten çok uzakta ve kaybolmuş olan modern Türkiye' nin beklenmedik şekilde anaerkil bir topluluğunda, deneyimlerin aktarılış şeklini irdeler". Yazar, filmin sonunda Nesrin' in sergilediği davranışlar hakkında da yorumda bulunur ve onun tavrını muhafazakârlığa, dine karşı bir "özgürleşme, bireyselliğini ve bağımsızlığını doğrulayan kahramanca ve trajik bir gösteri" olarak niteler (Pellegrini 2015). Ancak yine de Nesrin için rotanın belirsizliğine vurgu yapar. Nihayetinde filmi "Türk sinemasını yücelten insanlık halleri ve öyküleri" olarak çerçeveleyen Pellegrini, filmi tüm karşıtlıklarıyla ve çelişkinlikleriyle kökleri geçmişte olup geleceğe yayılan bir günümüz Türkiyesi'nin öyküsü olarak görür:

Senem Tüzen güçlü ve sade görüntülerle gelenek ve dinle yoğrulmuş bir geçmiş ve yeni bakış açılarının koruyucusu olan şimdi arasındaki ve en nihayetinde bir anne ve kız arasındaki, sadece ideal değil, aynı zamanda gerçek hesaplaşmayı bizlere anlatır. Anlatılan, bugünün Türkiyesi'dir (Pellegrini 2015).

Böylece ilk gösteriminde film eleştirmenleri tarafından filmin; geçmiş ile şimdi, anne ile kız, eski ile yeni arasındaki çatışmaya sahne olmuş günümüz Türkiyesi'nin bir temsili olarak etiketlendiği görülür. Bu tür bir etiketlemeyle filmin, Batılı bir öznenin beklentilerine yanıt verecek biçimde kodlanması dikkat çekicidir. Zira filme dair kullanılan ifadeler, Batılı seyircinin Doğu hakkındaki beklentilerini kaşır: Gelenekler ve kurumsallaşmış dinin baskısı al- 
tında var olma, özgürlük mücadelesi veren kadın öyküsü; geleneksel ile modern, eski ile yeni, kent ile kır arasında sıkışmış çatışmalı bir toplum ve kültür olarak Türkiye. Yer yer oryantalist söylemin sızdığı eleştiriler, aynı zamanda filmi bir kadın öyküsü olarak çerçeveler.

\section{"Yıkıcı ve cesur bir kadın filmi" olarak Ana Yurdu}

Ana Yurdu, bir "kadın öyküsü" olarak da etiketlenir. Filmin web sayfasında İtalyan Film Eleştirmenleri Derneği'nden Mariealla Cruciani'nin “Eşine az rastlanır bir kadın portresi”, "kendine özgü bir derinliğe sahip komplike ve cesur bir film" (2019); Cineuropa'nın ise "Anne-kız ilişkilerine dair yeni bir bakış açısı" (2015) olarak nitelediği görülür. FIPRESCI üyesi Ohad Landesman, ${ }^{7}$ Uluslararası Varşova Film Festivali'nde izlediği film için şunları söyler: “O kadar güçlü ve yoğun bir insan öyküsü ki sizi nefessiz birakacak!.. Sözünü esirgemeyen yıkıcı bir film... Bir kadının tek başına verdiği mücadelenin çarpıcı bir gerçeklikle dikkatlice filme dönüştürülmüş, ilham verici öyküsü" (Landesman 2015). Filmin öyküsünün duygusal etkileme gücüne vurgu yapan Landesman, boşanması ve anne olmayı reddetmesi nedeniyle Nesrin'i cesur bir kadın olarak görür ve filmin, anne-kız arasındaki ilişki üzerinden, Türkiye hakkında bir gerçeği ortaya koyduğunu vurgular:

İkisi arasındaki dinamikler; konformizm ve isyan, gelenek ve modernlik arasındaki çok daha büyük bir çekişmenin simgesi haline gelir. Bu durum Türkiye`de varolan önemli bir ulusal sıkıntıya işaret eder: Milyonlarca insan, özellikle kadınlar, yeni ve modern bir hayat yaşıyor olsalar dahi, ailelerinin geleneksel yetiştirme tarzıyla uzlaşmak zorunda kalmaktadırlar (Landesman, 2015).

Böylece film, özgürleşme mücadelesinde gelenek ve baskıcı toplumsal yapı tarafından ezilen kadınların öyküsü olarak etiketlenmiş ve modern/ muhafazakâr, özgürlük/kuşatılmışlık, Batı/Doğu, kent/ köy gibi bir dizi yerleşik karşıtlıkla çerçevelenmiş olur. Bu tür bir çerçeveleme, ileride de vurgulandığı üzere oryantalist bir tını içerir ve feminist bir söyleme işaret eder. ${ }^{8}$ Landesman, filmin, "dar sokakları, küçük iç mekânları ve dondurucu iklimiyle”

7 Ohad Landesman, Aleksander Huser ve Barbara Giza ile birlikte 31 Uluslararası Varşova Film Festivali'nin üç jüri üyesinden biridir (http:/ / fipresci.org/ festival/31st-warsaw-filmfestival/ 2015. Erişim tarihi 24 Aralık 2019).

8 Eleştirilerde Türkiye, egzotik bir uzak ülke olarak etiketlenmese de ona dair yapılan betimlemelerde öne çıkan bu ikili karşıtlıklar, Batılı bir bakışa/göze işaret eder. Bu bakış, Batılı toplum ve bireyden farklı olanı vurgular. de Valck Batılı olmayan ülkelerden gelen filmlerin festivallerde gösterilmesini, neredeyse bu farklılıkların sergilenmesine bağlar (2007). 
köyü Nesrin için hapishaneye benzeten sinematografisinin mükemmelliğini de över. Karanlık ve kostrofobik atmosferi, Nesrin'i din ile aile bağları arasına sıkıştıran minimalist sahne düzenlemesi de bu övgüler arasında yer alır. Filmde, anneannenin ve erkeklerin eksiklikleriyle var olduklarını anımsatan Landesman, yalnızca kadınların yaşadığı, yemek pişirdiği, dedikodu yaptığı ve acılarını paylaştığı köyde, onların yüreklerine kimsenin su serpmediğini belirterek kadınlararası dayanışma yokluğuna işaret eder (2015). Eleştiride filmin geçtiği coğrafya, kültür, toplum, mekân, anne-kız arasındaki gerilimli ilişkiye ek olarak öykünün belirsiz sonuna yer verilir:

Bu yoğun ancak sade öykünün pürüzlü zemini, en sonunda detaylarını burada vermeyeceğim tektonik bir kaymayla sonuçlanır. Bu amansız, sözünü esirgemeyen yıkıcı bir film, neredeyse hiç teselli ve huzur barındırmayan bu filmde trajik bir netliğe sahip tek andır. Ana Yurdu bir kadının tek başına verdiği mücadelenin çarpıcı bir gerçeklikle dikkatlice filme dönüştürülmüş, ilham verici öyküsü ve çarpıcı şekilde gerçek bir film. Haşin, fakat keskin film dili ise ara ara akla Nuri Bilge Ceylan'ın çok övülen Kış Uykusu filmini getirir. Kış Uykusu'nda da iki insan arasındaki gergin ilişkiye dair keskin bir bakış vardır. Diğer anlarda ise bu film, Türk sinemasının içinde bulunduğu duruma dair ferah ve yüksek derecede yaratıcı bir güç gösterisidir (Landesman 2015).

Filmin sonunu, yer bilimleri literatüründeki "tektonik kayma" sözcüğüyle niteleyen ve filmin sonunun vuruculuğunun altını çizen Landesman'ın eleştirisinde iç acıtıcı, trajik, haşin ve keskin diliyle film, ikinci kez Nuri Bilge Ceylan'ın Kış Uykusu filmine benzetilip filmin, sanat filmi olarak beslendiği damara işaret edilir. Tam da bu nedenle filmin sanat filmi olarak etiketlenmesinde uluslararası festivallerin ve eleştirmenlerin rolü vurgulanmış olur. Ana Yurdu ile Kış Uykusu arasında kurulan bu bağ, aynı zamanda Batılı seyircilerde Türkiye'ye dair imgelerin oluşturulmasında festivallerde gösterilen sanat filmlerinin belirleyici rolüne işaret ederek festivallerin ülke imgelerinin inşasındaki rolünü hatırlatır.

Landesman'ın eleştirisinde filmin hem saygın bir festivalde gösterildiği ve ödül aldığı hem de seyirci tarafından da beğenildiği vurgulanır. Böylece Neale'in belirtmiş olduğu gibi filmin uluslararası film festivallerinde ödüllerle "sanat filmi" niteliği onaylanmış ve meşrulaştırılmış olur. Filmin, karşıt duyguların çarpıştığı bir anne-kız ilişkisine odaklanmasıyla hem evrensel bir sorunu konu edindiği hem de modern Türkiye hakkında bilgi vermesiyle yerelden kopmadığı belirtilir (Neale 2010, 110). 
Ele aldığı gerilimli anne-kız ilişkisinin ardındaki toplumsal cinsiyet pratiklerini biçimlendiren politik kültüre de gönderme yapmasıyla Ana Yurdu, güçlü bir eleştiridir. 8 Nisan 2020 tarihinde Uluslararası Kadın Filmleri Festivali Malmö'de (IFEMA - International Female Film Festival Malmö) gösterilen Ana Yurdu için festivalin web sayfasında yönetmen Senem Tüzen'den yapılan alıntı, filmi tam da bu çerçeveye yerleştirir:

Yönetmenin kendisinin söylediği gibi Ana Yurdu, Türkiye'de, Nesrin gibi milyonlarca insanın, ebeveynleri geleneksel köylerden göç ettikten sonra modern şehirlerde büyüdüğü Türkiye'de kurulmuştur. Bu çocukların birçoğunun bakış açları ve beklentileri, genellikle ebeveynlerinin geleneksel ve dinsel yaklaşımlarından uzaktır. Modern Türkiye' de bu çatışma, bazı insanların ailelerinin ve içinde büyüdükleri modern toplumun etkilerini bütünleştirmesini zorlaştırmaktadır. Bu özellikle Türkiye' deki genç kadınlar için geçerlidir (IFEMA 2020).

Tanıtıma yerleştirilen yönetmenin açıklaması, filmi kurmaca olmaktan çıkararak gerçek dünyaya bağlar ve belgesel gibi değerlendirilmeyi talep eder. Böylece film, anne-kız arasındaki çatışmalı bir ilişkiyi anlatmaktan çok Nesrin gibi geleneklerin baskısında kalmış modern ve eğitimli kadınların yaşadı̆̆ı Türkiye hakkında antropolojik ya da sosyolojik bir belgeye dönüşür.

Benzer biçimde Kaya Genç de Daily Sabah'ta yer alan ve yönetmenle yapılmış söyleşiye dayanan eleştirisinde filmin otobiyografik niteliğini öne çıkarır: "Ana Yurdu, Bir Türk yönetmenin annesiyle yüzleşmesini araştırıyor" (Genç 2016). Tüzen'in ağzından, filmin anne ve babasının memleketi olan Niğde'de çekildiği bilgisi de yazıya eklenerek film, yönetmenin kişisel öyküsü olarak tanımlanmış olur. Tüzen de filmin hem Nesrin'in köye bireysellik getirmesi anlamında hem de sanatsal yaratımın doğası nedeniyle kişisel olduğunu vurgular: "Kendi ruhunu içinde yaşadığı dünyaya ince bir davul derisi gibi yayan bir sanatçı için her yapım kişiselleşir" (Genç 2016). Genç, “üzücü" ve "izleyiciye potansiyel bir romancinın ve annesinin sorunlu psikolojileri hakkında bir fikir vermesi nedeniyle keskin olarak rahatsız edici" olduğunu söylediği filmi, bazı sahneleriyle Luis Buñuel'in sürrealist filmlerine ve varoluşsal temasıyla "bir kadının bireyselliğinin maskesi arkasına saklanma ve karakterinin gerçekliğini keşfetme mücadelesini sergileyen” Ingmar Bergman'ın Persona filmine benzetir (2016). Gerek Tüzen'in açılamaları gerekse Genç'in modernist filmlerle kurduğu bağlar, Ana Yurdu'nun beslendiği damara işaret ederek onu sanat filmi olarak tanımlamaya çağırır. 


\section{Kușak çatıșması anlatısı olarak Ana Yurdu}

Ana Yurdu'na ilişkin eleştirilerde karşımıza çıkan bir başka tema ise kuşak çatışmasıdır. Bu tema, filmin 35. İstanbul Film Festivali'ndeki (2016) gösterimi kapsamındaki eleştirilerinde belirgindir. ${ }^{9}$ Bunlardan ilkinde Fipresci'nin web sayfasında yayımlanan "Drama of Generational Exchange" başlıklı eleştirisinde Viera Langerova, ebeveynler ve çocuklar arasındaki ilişkilerin sorunları hakkında öyküler anlatmaya olan yoğun ihtiyacın, her zaman yaklaşmakta olan veya devam eden toplumsal değişimleri gösterdiğini ve aile öykülerinin genellikle daha geniş sosyal çatışmaları yansıtan bir ayna işlevi gördüğünü belirterek, filmi "kuşak çatışması anlatııı" olarak çerçeveler (2016).

Festivaldeki ulusal yarışma filmlerini ${ }^{10}$ birlikte değerlendiren Langerova, aile ve kuşak çatışması temasını, daha geniş tarihsel, toplumsal ve politik bir bağlam içinde ele alır. Çünkü "küreselleşen dünya, mevcut kültürel ve sosyal stereotiplerin net biçimlerini bulanıklaştırmış ve ailenin işleyişi ile ilgili daha karmaşık sorular ortaya çıkarmıştır". Eleştirmen bu yönüyle aralarında Ana $Y u r d u$ 'nun da dahil olduğu festivaldeki ulusal yarışma filmlerini "gerçek bir kuşak çatışması"; "geleneksel olarak gerçekçi öykülerin arkasında metaforik bir temsili" biçimde okuyabileceğimizi söyler. Langerova, sonu çıkıssızlıkla biten filmdeki anne-kız arasındaki çatışmayı da gündelik yaşamın dini kurallara göre yeniden inşa edilmeye zorlandığı Türkiyesi'nde bu baskılara karşı direnişin bir metaforu olarak okur. Böylece erkekleri göremediğimiz ve çatışmaları çıkmazla sonuçlanan anne-kızdan oluşan aile, Türkiye'nin bir temsiline dönüştürülmüş olur. Langerova'ya göre bu filmlerin öyküleri, baskın ebeveynler tarafından yönetilen ailenin çekiciliğini doğrular. Sert ve baskıcı düzenle yüzleşen filmlerin kahramanları, pişmanlık içinde kıvranırlar (Langerova 2016).

Çünkü kendi yollarına gitme arzuları, aileyi ve temsil ettikleri geleneği terk etmek anlamına gelir. Onlar, gerçekleştirilmemiş fikirlerde ve hayallerde debele-

9 Festivalin, Müjde Ar'ın başkanlığındaki diğer ulusal yarışma jüri üyeleri şu isimlerden oluşmuştur: Oyuncu Tansu Biçer, yazar ve yönetmen Ben Hopkins, oyuncu ve yönetmen Niki Karimi, yazar Murat Uyurkulak ve dağıtımcı Torsten Frehse.

10 Bu filmler şunlardı: Benim Kendi Hayatım (Adnan Akdağ, 2015), Rüzgârın Hatıraları (Özcan Alper, 2015), Siyah Karga (Tayfur Aydın, 2016), Kalandar Soğuğu (Mustafa Kara, 2015), Rauf (Barış Kaya, Soner Caner, 2016), Mavi Bisiklet (Ümit Köreken, 2016), Toz Bezi (Ahu Öztürk, 2015), Rüzgârda Salınan Nilüfer (Seren Yüce, 2016), Kasap Havası (Çiğdem Sezgin, 2015) ve Ana Yurdu (Senem Tüzen, 2015). 
nen, hayatlarını isteklerine göre biçimlendiremeyen yalnız ve çaresiz insanladır, değişme umudu çok azdır. Sosyal statükonun bu grup portresi kasvetli ve kötümserdir. Bunun gerçek duruma ne ölçüde karşılık geldiği ve ataerkil zorunluluklara karşı ne kadar ortak bir direnişin gösterisi olduğu tartışmalıdır. Kuşak çatışması dramlarının ardında sadece muhafazakârlığın ve ataerkil iktidarın dönüşüne karşı değil, aynı zamanda kentleşmiş şehirler ve az gelişmiş kırsal alanlar arasında daha geniş bir mücadele olduğunu da görebiliriz. Görünüşe göre hala derin bir yarılma ile bölünmektedirler (Langerova, 2016).

Böylece Langerova'nın Ana Yurdu analizi, aynı dönemde üretilen diğer Türk filmlerinin tarihsel, toplumsal ve politik bağlamına ilişkin tanımlayıcı ve kuşatıcı bir çözümlemeye dönüşerek filmin üretildiği toplumsal dinamiklere 1ş1k tutar.

Patrizia Pistagnesi de 35. İstanbul Uluslararası Film Festivali kapsamında gösterilen filmler üzerine yazdığı eleştiride, büyük bir yönetmenin zamanının ve ülkesinin iç hastalığını; özgün, duygusal ve benzersiz bir estetik biçimde anlayabileceğini ve yeniden yaratabileceğini söyler (2016). Bu ifade, Pistagnesi için büyük bir yönetmen olmanın koşulunun, psikolojik ve sosyolojik bir kavrayış gücü ile estetik bir ustalık olduğuna işaret eder. "The Landscape of the Unconscious" (Bilinçaltının Manzarası) başlıklı eleştirisiyle Pistagnesi, filmleri toplumun psikanalitik bir ifadesi olarak kavradığını ima eder. Türkiye'nin toplumsal sorunları, acıları aynı olsa da Pistagnesi, festivalin ulusal yarışma filmlerinin yönetmenlerinin, bunları kendilerine özgü bir perspektifle ifade ettiklerini vurgulayarak üsluba ya da biçeme vurgu yapar ve Ana Yurdu'nu bu türdeki senaryonun en etkileyici ve başarılı örneği olarak değerlendirir. Jüri olarak “insanın kimlik ve özgürlük arayışını çizerken sinematik bir dil aracılığıyla evrensel anlam ve duygu iletme yeteneği nedeniyle" Senem Tüzen'i ödüllendirdiklerini açıklar (Pistagnesi, 2016). Festivalin ulusal kategorisindeki yönetmenlerin, coğrafi ve/veya sembolik manzaralarına derinden bireysel bir bakış gösterdiklerini söyleyerek şöyle devam eder:

Genel olarak çocukluklarının geri dönmeye zorlandıkları büyüleyici, arkaik, boş köyler, kökler, aile, din ve gelenekler ile gerçeklik ya da hayal kırıcı, yalnız, aptal bir şehir hayatı arzusu arasında az ya da çok bilinçli içsel çatışmalardır. Kaçmak zor ve acı verici bir deneyimdir ve geçmiş asla bitmez... çoğu zaman henüz geçmiş değildir (Pistagnesi, 2016).

Pistagnesi'nin eleştirisinde köy ve kent bir yerleşim yeri olmaktan öte toplumsal, tarihsel ve psikolojik anlamlarıyla tanımlanmıştır. Köyler akılla kavranması imkânsız bir gizemle neredeyse tarih öncesi bir zamana ait k1- 
lınarak aidiyet, din ve gelenekle; şehirler ise gerçekçi olanla hüsranla ve yalnızlıkla ilişkilendirilmiştir. Bu keskin yarılmaya karşın eleştirmen, geçmişin şimdi üzerine bütün tortusuyla çöreklendiği, geçmişin, tarih-öncesinin hep şimdiye aktığı bir zamansallık çizer ki bu zamansallık ileri doğru değildir, döngüseldir; kaçışa da olanak vermez. Böylece filmin zamanı, ilerisi olmayan, geçmişin bir hayalet gibi şimdiye musallat olduğu aynılıkta sabitlenmiş olur.

Pistagnesi, Ana Yurdu’nda anne ile kızı arasındaki çatışmanın, aynı zamanda seyircinin kendi içinde bulabileceği evrensel bir bölünmüşlüğü ifade ettiğine işaret eder ve karakterlerleri iyi-kötü olarak ayıramayacağımızı belirtir. Sanat filmlerine ait bu saptamalar, eleştirmenin filmi ilişkilendirdiği diğer yönetmenlerle de güçlendirilir. Pistagnesi, filmi hem yönetmenin kişisel üslubu nedeniyle Nuri Bilge Ceylan aracılığı ile sanat sinemasına bağlar hem Bergmanvari dokunuş nedeniyle Avrupa sanat sinemasıyla ilişkilendirir (2016). Pistagnesi'nin gönderme yaptığ film, anne, eş ve oyuncu rollerine karşı gelerek konuşmayı reddeden Elisabeth ile ona bakmakla görevlendirilmiş hemşire Alma arasıdaki ilişkiyi anlatan Persona'dır (Ingmar Bergman, 1966). Persona, bireyin varoluş mücadelesini anlatan (Akbulut 2004), Avrupa sanat sinemasının, "yüksek modernizmin mükemmel bir örneği" (akt. Ford, 2002) olarak değerlendirilir. Ana Yurdu hem kimlik inşasının psikolojik ve kolektif bilinçaltındaki süreçlerine odaklanmasıyla hem de modernsit üslubuyla Persona'ya benzer. Pistagnesi, Ana Yurdu'nda, aynı yatakta ağlayıp gülerek konuştukları sahnede Nesrin ve annesi arasındaki yakınlaşmanın ya da birleşmenin imkânsızlığının, benzer bir dille, karakterleri birbirinden ayıran çerçevelemelerle anlatıldığını yazar. Böylece Ana Yurdu hem öyküsüyle hem de bu öyküyü anlatış biçimi ve modernist üslubuyla sanat filmi olarak etiketlenir.

\section{Kadının kimlik ve kök arayıșı olarak Ana Yurdu}

Ana Yurdu'nun 35. İstanbul Uluslararası Film Festivali'ndeki gösterimine ilişkin bir başka yazı ise Senem Erdine tarafından yazılmıştır. Erdine de ulusal kategoride yarışan filmlerde bir ortaklık saptar ve bu filmlerin birçoğunun kimlik aramak için köklere, aileye, anavatana geri dönüş hakkında konuşmasının bir tesadüf mü, yoksa sosyal, etnik, dini ve kültürel kimliklerinde ciddi bir şekilde kutuplaşmış olan günümüz Türkiyesi'ndeki siyasi atmosferin bir yansıması mı olduğunu sorar. "Back to Roots in Search of Identity" (Kimlik Arayışında Köklere Dönüş) başlığı ile birlikte bu ifade, Ana Yurdu'nu, diğer ulusal yarışma filmleri gibi Türkiye'nin tarihsel ve toplumsal döneminin bir temsili olarak işaretler. Erdine'ye göre Ana Yurdu, anne-kız ilişkisinin çatışmacı doğasına yeni bir yaklaşım getirir. Eleştirmen, filmin öyküsünü kısaca ak- 
tardıktan sonra yönetmenin anne-kız çatışmasını "ikna edici, derinlemesine, açıklayıcı ve etkileyici bir ilişki analizi" yaptığını söyleyerek onun becerisini över. Bu övgüye, Nesrin'in istek ve duygularını ustaca anlatan kamera çerçevelemelerini de ekler. "Film ustaca gerginlik yaratıyor ve seyirciyi güçlü bir son sahneye hazırliyor". Nihayetinde Ana Yurdu, "bir anne ve kızı arasındaki ilişkinin çatışan doğasını ve bir kadının özgürlük ve kimlik arayışını betimlemede özgün, evrensel, cesur ve etkili olan genç ve gelecek vaat eden bir yönetmenin dikkat çekici bir filmi" olarak çerçevelenir (Erdine 2016).

Ana Yurdu, festival gösterimlerinin yanı sıra özel gösterimlerde de seyirciyle buluşmaya devam eder. Bu etkinliklerden biri, filmin 15 Eylül 2019'da Indiana Üniversitesi Sineması'nda, “Ekranı Yönetmek: Kadınların Tarafından Yapılmıştır" gösterimi kapsamında "Dünyalar Arasında: Türk Filmlerinde Kültürel Melezlik" başlığıyla gösterimidir. "Çoklu kültürel bağlılıkların kimlik veya kültürel karışım süreci üzerindeki etkileri ile ilişkili olan" (Papastergiadis 2005,40 ) bu postkolonyal terim, filmi de bu kavramla ilişkilendirmeye çağırsa da gösterim öncesi Zeynep Yasar'ın yazdığı eleştiri, filmi feminist bir söylemle çerçeveler. Yasar (2019), Nesrin'in köyde geçirdiği zamanın, onun "hayal ettiği tüm aşinalık ve anne kucaklaması ile kuşaklar arası gerginliklerin ataerkil baskı ve içselleştirilmiş kadın düşmanlığının çoklu tarihlerinin temelinden yüzeye çıktığı acı verici bir bölüme dönüştüğünü” söyler (2019). Filmi daha çok Halise'nin dramı olarak okuma eğiliminde olan Yasar'ın analizi, anne ve kızdan birini suçlu, diğeri kurban ilan etmek yerine, onları böyle davranmaya iten nedenleri tartışarak kadınlık ve kadınlararası ilişkileri biçimlendiren kolektif bilinçaltındaki kavrayışları açığa çıkarır ve kadınlararası ilişkilerin arkeolojisini yapmaya soyunur.

Ana Yurdu, ataerkilliği, kadınların ezilmesinin sadece zehirli erkekliğin tezahürleri yoluyla değil, kadınların birbirlerinin pahasına sık sık hayatta kalmaya çalıştıkları eylemleri ile sürdürüldüğü bir tuzak olarak gösterir. Bunu, filmin çoğunu oluşturan iç mekân sahnelerinde dar çerçeveli ve loş 1şıklı çekimler ve izleyiciye kalıcı bir gözetleme duygusu ileten kamera açıları ile yapar (Yasar, 2019).

Böylece Yasar'ın eleştirisi, Ana Yurdu'nu güçlü sinematografisiyle kadınlığın ve kadınlararası ilişkilerin inşasında görünmeyen tehlikeler konusunda seyirciyi uyaran, eleştirel feminist bir film olarak etiketlemiş olur.

Ana Yurdu, 3-11 Temmuz 2020 tarihleri arasında düzenlenmesi planlanan, ancak Covid-19 pandemisi nedeniyle ertelenen Karlov Vary Uluslararası Film Festivali'nin "Belirli bir Bakış" bölümünde de gösterim programına 
alınır. Film için kaleme aldığı yazısında Kamila Dolotina, filmin sinopsisini aktardıktan sonra onu şöyle etiketler: “Bu ilk film, özgürleşmeyi kabul eden ancak buna tahammül edemeyecek olan çağdaş Türk toplumunun psikolojik olarak yıkıcı bir portresini sunuyor" (Dolotina 2020). Bu tanımlamayla film, bireyleşme ve modernleşme sürecinde teori ve pratik arasındaki çelişkiye işaret ederek Türkiye'nin bir temsili olarak konumlandırılmış olur. Eleştiride köyün tutuculuğu, iki kadın arasındaki ilişkinin düzelmesinin olanaksızlığı gibi temalar ve filmin görsel dilinin gücü gibi biçemsel özelliklere vurgu yapılması göze çarpar. Dolotina, Nesrin'in döndüğü köyü “Türk taşrası” olarak niteleyerek buranın farklı amaçları olan özgür bir kadın için ideal bir yer gibi görünmediğini belirtir. Çünkü yazara göre Nesrin, "muhtemelen ön kapılarının dışına hiç adım atmamış kadınların düşmancıl alayları ile çevrilidir ve muhafazakâr annesinin gelişiyle birlikte yoğunlaşan engellere ve önyargılara karşı gelir". Dolotina "anlayışlı psikolojik portre" olarak tanımladığı filmde anne ve kızı arasında ortak bir zemin bulamama nedenini de hem iki kadının hayat görüşleri arasındaki radikal farklılığa hem de geçmişten gelen çözülmemiş haksızlıklara bağlar. Eleştirmene göre "filmde tasvir edilen haksızlığın döngüsel doğası sayesinde parçalanmış öykü, neredeyse mitolojik bir görünüm kazanırken aynı zamanda çağdaş Müslüman toplumdaki mevcut kuşak ve dinsel bölünmeleri yansıtan bir ayna görevi görür" (Dolotina, 2020).

Dolotina'nın yazısı, anne-kız arasıdaki ilişkinin, yalnızca şimdinin değil, neredeyse coğrafyaya yazılı bir kalıt tarafından belirlenmiş olduğuna işaret ederek, İbn-i Haldun'un Mukaddime (2020) adlı eserinde anlattığı gibi “coğrafya kaderdir" önermesini akla getirir. Yaşanılan yerin ve coğrafi koşulların, üzerinde yaşadığı insanların düşünme biçimlerine, alışkanlıklarına, sorunlarına dek tüm yaşamlarını biçimlendirdiği anlamına gelen İbn-i Haldun'un bu özdeyişi, Ana Yurdu'nda gördüğümüz, tanık olduğumuz sorunların geçici değil, yerleşik ve değişmez olduğunun altını çizerek oryantalist bir söyleme işaret eder. Böylelikle filmin baskıcı, muhafazakâr bir toplumda var olmaya çalışan bir kadının özgürleşme çabası biçiminde çerçevelendiği görülür.

\section{Sonuç: Bir Türkiye metaforu olarak Ana Yurdu}

Elsaesser, filmlerin belli bir oranda festivaller için üretildiğini varsaydığımızda film üzerindeki gücün film yönetmeninden, festival direktörüne geçtiğini belirtir ve bu gücün, festival direktörünü "görsel sanatçılar ve sergi alanları üzerinde kontrol kuran "yıldız küratörlere" benzettiğini söyler $(2005,93)$. Küratörlere, festivaller ile sanat sineması alanında söz sahibi ve filmler üzerine yazdıklarıyla filmin daha sonraki gösterim serüveninde yönlendirici olmalarından dolayı film eleştirmenlerini de ekleyebiliriz. 
Ana Yurdu'nun festival gösterimleri bağlamındaki film eleştirilerine odaklanan bu çalışma, filmin "kadın filmi", "sanat sineması", "geleneksel / modern çatışması", "kuşak çatışması", “köklere dönüş", "kimlik arayışı”, “özgürleşme mücadelesi", "yarılmış bir ülkenin temsili" gibi kavram ve temalarla çerçevelendiğini ve temelde "günümüz Türkiyesi'nin metaforu" olarak etiketlendiğini ortaya koymuştur. Eleştiriler, filmi başat biçimde, anne-kız ilişkisi aracılığıyla geleneksellik ve modernlik arasında arafta kalmış Türkiye'nin bir metaforu olarak çerçeveler. Bu yazılarda film, anne-kız ilişkisi ve çatışmasının evrensel olmakla birlikte, yerelde yaşanma biçimini ifade ettiği için dikkate değer bulunmaktadır. Böylece eleştirilerde, filmin sosyolojik bir alegori olarak değerlendirildiği anlaşılır. Eleştiriler, aynı zamanda kapalı alanları, dar çerçevelemeleri ve karanlıkta bırakan loş aydınlatması nedeniyle filmin sinematografisini de övgüye değer bulur ve onu hem Batıda çok tanınan Türkiyeli yönetmen Nuri Bilge Ceylan'ın içinde olduğu ulusal sanat sineması damarına hem de Bergman çağrışımlarıyla moderist Avrupa sinemasına bağlarlar. Sanat sinemasına bağlanan yol, evrensel temaların yerel (ulusal) olanı ifade edecek bir anlatı ve modern bir stil repertuarı eşliğinde anlatılmasından ileri gelir.

Evrensel temaların, çatışmaların ya da sorunsalların yerel örnekler üzerinden anlatılıyor olması, Türkiye gibi Batılı olmayan ülkelerden filmlerin Batılı festivallerde gösterilmesinin, neredeyse ön koşulu olduğu tartışmasını anımsatır. Böylece festivaller ve eleştirmenler, van Dijk'ın adlandırdığı gibi "ideolojinin yeniden üretimi sürecinde birtakım araçların, kurumların ya da süreçlerin yönetiminde olan ve sistem için kritik bir öneme sahip kişilerden" oluşan aktörler olarak öne çıar $(2005,324)$. Ana Yurdu'nun evrensel olan anne-kız ilişkisinin çatışmacı doğası aracıllğııla modern ve geleneksel, Batılı/Doğulu, eğitimli/ eğitimsiz, gelişmiş/gelişmemiş, uygar/cahil, kent/taşra ikilikleri arasına sıkışmış günümüz Türkiyesi'nin bir ifadesi olarak değerlendirilmesi; filmin, Dissanayeke'nin tanımladığı haliyle "ulus devlete eleştirel açıdan bakan ve uluslararası değerlerle karşılaştıran uluslararası festivallerde gösterim amaciyla üretilmiş sanat filmi" (1998: 529) olarak kavramsallaştırmasını akla getirir. Tam da burada, ülke sinemalarına, yani ulusal sinema kültürüne ait filmlerin uluslararası festivallerde gösterilmesi için gereken iki anlatı damarından birine ait olarak kodlanmış olması gerektiğini belirten de Valck'ın vurgusunu anımsamak yerindedir. de Valck'e göre bu kodlar steril bir içeriğe sahip olan, tehlikeli sulara girmeyen apolitik anlatılar, diğeri, öteki konumunu kuran ve koruyan, turistik bakışı yansıtan, egzotik, oryantalist kültür ve kültürel kimliklerle 'dünya sineması' anlatılarından oluşur (2007). Eleştiriler, Ana Yurdu'nu tümüyle bu keskin tanımlama içinde görmeseler de 
filmin anlatısal ve görsel yapısından seçtikleri özelliklerle onu kişisel olan aracılığıyla toplumsal, kültürel, ulusal ve evrensel olanın ifade edildiği, arafta kalmış bir toplumun temsili olarak tanımlarlar. Cindy Wong, bir "festival filmi" ni tanımlayan özellikleri "ton"da ciddilik, mizansen içinde tasarruf ve minimal estetik ile açık anlatılar olarak kategorize eder. Yazara göre filmlerin önemli bir kısmı karakter portreleridir ve anlatılar gösteri yerine "küçük anlara" yaslanır. Son olarak bu filmlerin çoğu Wong'un sözleriyle "gündelik" olanın duygusuna ulaşmak için aktör olmayan kişileri kullanarak gerçekçiliğe ulaşmaya çalışır (akt. Falicov 2016, 214). Eleştiriler, Ana Yurdu'nun bu özelliklere sahip ulusal sanat sinemasının örneği olan bir festival filmi olarak nitelenebileceğine işaret eder. Bu yazılarda baskıcı bir çevre, anne-kız arasındaki gerilimli ilişki, karanlık klostrofobik alanlar, içerikte ve biçimde ciddiliğin; çoğunlukla yakın ve durağan çekimler ise minimal estetiğin göstergeleri olarak öne çıkar. Bunlar, Elsaesser'in tanımladı̆̆ı haliyle (2005) uluslararası festival filmlerinin stil repertuarına ait öğelerdir. Film, neden-sonuç ilişkisiyle kurulan klasik bir öykülemeye değil, annesinin baskıları karşısında Nesrin'in davranışlarına odaklandığı için "anlarla" ilerler. Nesrin ve Halise dışındaki karakterlerin köylüler tarafından oynandığı film, oyunculuğuyla da son derece gerçekçidir ve tanıdıklık hissi oluşturur. Sonuç olarak Ana Yurdu eleştirilerinde filmin, anne-kız ilişkisinin çatışmacı doğasına farklı perspektifle yaklaşan, köklere dönerek kimliğini arayan "bir kadın öyküsü" ve birey/cemaat, modern/geleneksel, kent/köy, özgürlük/ esaret gibi karşıtlıklar arasında salınan günümüz Türkiyesi'nin bir metaforu olarak etiketlendiği açığa çıkarılmıştır. Bu etiketlemeler filmin üç yönüne odaklanır: Öncelikle yazılarda filmin öyküsü/ sinopsisi aktarılır. Ardından anlatı içinde karakterlerin çatışması ve bu çatışmanın temsil ettiği anlamlar öne çıkarılır. Anlatıda gerilimin aşama aşama kurulmasında senaryonun gücüne ve dolayısıyla yönetmenin becerisine atıf yapılır. Karşıtlıklarla tanımlanmış karakterler arasındaki çatışmanın mekân, çerçeveleme ve aydınlatma yani etkili bir sinematografiyle görselleştirildiği ifade edilir. Bu sıralamalar, bunları başaran bir özneye, yönetmene işaret eder. Anne-kız ilişkisinin, birey olamama halinin, benliğin ve toplumun yarılmasının altında yatan dinamiklere ve kolektif bilinçaltına bakabildiği ve bunları etkili kişisel bir üslup içinde anlattığı için yönetmenin becerisi vurgulanır. Bu vurgu, henüz ilk filmi olmasına karşın Tüzen'e auteur bir nitelik atfedildiğini düşündürür. Böylece Allen ve Lincoln'ün açıkladıkları gibi $(2004,877)$ film festivalleri bağlamında Ana Yurdu'nun değerlendirilmesinde öncelikle ulusal sanat sineması söyleminin, ardından auteur yaklaşımın bir söylem olarak iş başında olduğu görülür. Filme ilişkin yazı ve eleştiriler, Ana Yurdu'nu ele al- 
dığı sorunlar, konular ve bunları işleyiş biçimiyle Neale'ın ifade ettiği gibi (2010, 108) ulusal kültür ve gelenekle ilişkilendirir. Böylece Doğu/Batı, geleneksel/modern, köy/kent, erkek/kadın, esaret/özgürlük gibi karşıtlıklar ve çatışmalar, Ana Yurdu'nu işaretleyen ulusal belirtiler olarak saptanır. Aynı zamanda bu sorunların, Nuri Bilge Ceylanı anımsatan işleniş biçimine yapılan vurguyla film, ulusal sanat sineması söylemi içinde çerçevelenir. Son olarak eleştiriler, filmin Andrew Sarris'in (2016, 42-43) işaret ettiği gibi Tüzen'in “teknik ustalığını"; benzer konu ve temaları farklı bir biçiminde kişisel bir uslupla işleyen yani ayırt edilebilen "kişiliğini" ve onun filmin konusu aracılığıyla yakaladığı "içsel anlamı” överler. Tüzen'in sosyolojik gözlem ve ifade gücü, klostrofobik ve anlatımcı mizansen, kuşatıcı çerçevelemeler, karakterleri yarı karanlıkta bırakan aydınlatma ve doğal oyunculuklarla belirlenmiş stil repertuarıyla birlikte film, Nuri Bilge Ceylan ve Ingmar Bergman çă̆rışımlarıyla sanat sinemasına bağlanır. Nihayetinde filmin sanat filmi nitelikleri; evrensel teması, günümüz Türkiyesi'nin bölünmüşlüğünün nedenlerine işaret eden sosyolojik tahayyül gücü, çatışmanın ustaca örüldüğü senaryo, yönetmenin kişisel üslubu, minimal sinematografi ve göndermeleri aracılığıyla kurulmuş olur. 


\section{Kaynakça}

Akbulut, Hasan. 2004. “Bir Varoluş Sorunsalı: Persona.” Kültür ve İletişim 7 (1): 71-100.

Allen, Michale Patrick ve Lincoln Anne E. 2004. "Critical Discourse and the Cultural Consecration of American Films." Social Forces 82 (3): 871-94.

Ana Yurdu Film. 2019. Erişim tarihi 24 Aralık 2019.

https:// anayurdu.com/.

Andrew, Dudley. 2010. "Foreword." Global Art Cinema: New Theories And Histories içinde, editörler Rosalind Galt ve Karl Schoonover, V-XI. New York: Oxford University Press.

Beyer, Eric, 2016. "In Conversation with Senem Tüzen, Director of Ana Yurdu (Motherland)." Erişim tarihi 21 Şubat 2020.

https://yabangee.com/senem-tuzen-ana-yurdu-motherland/.

Biltereyst, Daniël, Kathleen Lotze ve Philippe Meers. 2012. “Triangulation in historical audience research: Reflections and experiences from a multi-methodological research project on cinema audiences in Flanders." Participations: Journal of Audience \& Reception Studies 9 (2): 690-715.

Bordwell, David 2010. “Film Pratiğinin Kipi Olarak Sanat Sineması.” Çeviren Yeşim Özben. Auteur Kuram ve Sanat Sineması Üzerine içinde, editör Ali Karadoğan, 107-18. Ankara: De ki Basım Yayım Ltd. Şti.

Boxoffice. Erişim tarihi 5 Ocak 2020.

https:/ / boxofficeturkiye.com/ film/ana-yurdu-2013066.

Butler, Andrew. 2005. Film Studies. Vermont, Harpenden: Pocket Essentials.

Chandler, Daniel ve Rod Munday. 2018. Medya ve İletişim Sözlü̈̆̈̈. Çeviren Babacan Taşdemir. İstanbul: İletişim Yaynları.

Chatman, Seymour 2008. Öykü ve Söylem: Film ve Kurmacada Anlatı Yapısı. Çeviren Özgür Yaren. Ankara: De Ki Basım Yayım Ltd. Şti.

Cineuropa. 2015. “Motherland.” Erişim tarihi 24 Aralık 2019.

https:// cineuropa.org/.

Cooper, Brenda ve Edward C. Pease. 2008. "Framing Brokeback Mountain: How the Popular Press Corralled the 'Gay Cowboy Movie.'" Critical Studies in Media Communication 25 (3): 249-73.

de Valck, Marijke 2007. Film Festivals: From European Geopolitics to Global Cinephilia. Amsterdam: Amsterdam University Press.

de Valck, Marijke 2012. "Finding Audiences for Films: Programming in Historical Perspective." Coming Soon to a Festival Near You: Programming Film Festivals içinde, editör Jeffrey Ruaff, 25-40. St Andrews: St. Andrews Film Studies.

Desland, Ghislain ve Jocelyn Maxient. 2011. "Turkish auteur cinema and European identity: Economic influences on aesthetic issues." Journal of European Popular Culture 2 (1): 81-98. 
Dissanayeke, Wimal. 1998. "Issues in World Cinema." The Oxford Guide to Film Studies içinde, editörler John Hill ve Pamela Church Gibson, 527-34. Oxford: Oxford University Press.

Elsaesser, Thomas. 2005. European Cinema: Face to Face with Hollywood. Amsterdam: Amsterdam University Press.

Entman, Robert M. 1993. “Framing: Toward a Clarification of a Fractured Paradigm." Journal of Communication 43 (4): 51- 58.

Erdine, Senem. 2016. “Back to Roots in Search of Identity." Erişim tarihi 24 Aralık 2019. http:/ / fipresci.org/report/back-to-roots-in-search-of-identity /.

Fabe, Marilyn. 2004. Closely Watched Films: An Introduction to the Art of Narrative Film Technique. Berkeley, Los Angeles, Londra: University Of California Press.

Falicov, Tamara L. 2016. “The 'Festival Film': Film Festival Funds as Cultural Intermediaries.” Film Festivals: History, Theory, Method, Practice içinde, editörler Marijke de Valck, Brendan Kredell ve Skadi Loist, 209-29. New York, Londra: Routledge.

Fipresci. 2015. Erişim tarihi 24 Aralık 2019.

http:/ / fipresci.org/ festival/31st-warsaw-film-festival/.

Ford, Hamish (2002). “The Radical Intimacy of Bergman.” Senses of Cinema 23. Erişim tarihi 5 Ocak 2003.

http://sensesofcinema.com/2002/great-directors/bergman/.

Galt, Rosalind ve Karl Schoonover. 2010. "Introduction: The Impurity of Art Cinema." Global Art Cinema: New Theories And Histories içinde, editörler Rosalind Galt ve Karl Schoonover, 3-27. New York: Oxford University Press.

Genç, Kaya. 2016. "In Motherland a Turkish director explores an artist's confrontation with her mother." Dailiy Sabah. 30 Mayıs 2016. Erişim tarihi 24 Aralık 2019.

https:/ / www.dailysabah.com/ cinema/2016/05/30/in-motherland-a-turkish-directorexplores-an-artists-confrontation-with-her-mother.

Green, Michael. 2002. "Social contexts and uses of research: Media, education, and communities." A Handbook of Qualitative Methodologies for Mass Communication Research içinde, editörler Klaus Bruhn Jensen ve Nicholas W. Jankowski, 216-31. Londra, New York: Routledge.

Hall, Alice. 2001. "Film reviews and the public's perceptions of stereotypes: Movie critics' discourse about The Siege." Communication Quarterly 49: 399-423.

Harris, Sarah. 2008. "Turkish Popular Cinema: National Claims, Transnational Flows." The International Journal of The Humanities 6 (3): 77-87.

IFEMA Film Festival. 2020. Erişim tarihi 7 Nisan 2020. http://www.femalefilmfestival.se/motherland-2/.

Iordanova, Dina. 2016. "Foreword: The Film Festival and Film Culture's Transnational Essence." Film Festivals: History, Theory, Method, Practice içinde, editörler Marijke de Valck, 
Brendan Kredell ve Skadi Loist, XI-XVIII. Londra, New York: Routledge.

İbn-i Haldun (2020). Mukaddime. Yayına Hazırlayan Süleyman Uludağ. İstanbul: Dergâh Yayınları.

Jauss, Hans Robert. 1982. Literary History as a Challenge to Literary Theory. Minneapolis: University of Minnesota Press.

Landesman, Ohad. 2015. "All About My Mother in 35th International Istanbul Film Festival." Çeviren Begüm Gür Erdost. Erişim tarihi 24 Aralık 2019.

http:// fipresci.org/report/all-about-my-mother/.

Langerova, Viera. 2016. “Drama of Generational Exchange: National Competition of Turkish Films," in 35th International Istanbul Film Festival. Erişim tarihi 24 Aralık 2019. http:/ / fipresci.org/report/drama-of-generational-exchange-national-competition-ofturkish-films/.

Lev, Peter. 1993. The Euro-American Cinema. Austin: University of Texas Press.

Lockyer, Sharon. 2008. “Textual Analysis.” The Sage Encyclopedia of Qualitative Research Methods Volume 1-2 içinde Editor Lisa M. Given, 865-66. Los Angeles, Londra, New Delhi, Singapore: Sage Publications.

Lunn, Eugane. 1995. Marksizm ve Modernizm: Lukacs, Brecht, Benjamin ve Adorno Üzerine Bir Tarihsel İnceleme. Çeviren Yavuz Alagon. İstanbul: Alan Yayıncllı.

Mayring, Peter. 2011. Nitel Sosyal Araştırmaya Giriş: Nitel Düşünce için Bir Rehber. Çeviren Adnan Gümüş ve Sezai Durgun. Ankara: Bilgesu Yayıncılık.

Neale, Steve. 2010. "Kurum Olarak Sanat Sineması." Çeviren Özgür Yaren. Auteur ve Sanat Sineması Üzerine Yazılar içinde, editör Ali Karadoğan, 119-50. Ankara: De Ki Basım Yayım Ltd. Şti.

Noriega, Chon 1990. "Something's Missing Here!: Homosexuality and Film Reviews during the Production Code Era, 1934-1962." Cinema Journal 30: 20-41.

Öztürk, Ruken (2000). Sinemada Kadın Olmak: Sanat Filmlerinde Kadın İmgeleri. İstanbul: Alan Yayınclık.

Papastergiadis, Nikos. 2005. "Hybridity and Ambivalence Places and Flows in Contemporary Art and Culture." Theory, Culture \& Society 22 (4): 39-64.

Pellegrini, Luca. 2015. “Motherland, Venice Critics' Week." Çeviren Begüm Gür Erdost. Erişim tarihi 24 Aralık 2019. https: / / anayurdu.com/.

Pistagnesi, Patrizia. 2016. "The Landscape of the Unconscious in 35th International Istanbul Film Festival." Erişim tarihi 24 Aralık 2019. http:/ / fipresci.org/report/the-landscape-of-the-unconscious/.

Pramaggiore, Maria ve Tom Wallis. 2005. Film: A Critical Introduction 3. Ed. Londra: Laurence King Publishing Ltd.

Prince, Stephen. 1997. Movies and Meaning: An introduction to Film. Boston: Allyn and Bacon. 
Redhouse Sözlüğü. 2015. İngilizce-Türkçe Redhouse Sözlügüu. İstanbul: Sev Matbaacılık.

Sarris, Andrew. 2016. “1962'de Auteur Kuramı Üzerine Notlar.” Çeviren Barış Kılıçbay. Auteur Kuram ve Sanat Sineması Üzerine içinde, editör Ali Karadoğan, 65-70. Ankara: De Ki Basım Yayım Ltd. Şti.

Siska, Charles William. 1980. Modernism in The Narrative Cinema: The Art Film as a Genre. New York: Arno Press.

Staiger, Janet. 1992. Interpreting Films: Studies in the Historical Reception of American Cinema. Princeton: Princeton University of Princeton.

Staiger, Janet. 2000. Perverse Spectators: The Practices of Film Reception. New York: New York University Pres.

Staiger, Janet. 2005. Media Reception Studies. New York: New York University Press.

Suárez, Gonzalo. 2015. "Motherland: The traditional community and the modern individual come face to face." Cineuropea. Erişim tarihi 24 Aralık 2019. https:// cineuropa.org/en/newsdetail/298367/.

Yasar, Zeynep. 2019. "\#Crucial21DbW: Motherland/ Ana Yurdu directed by Senem Tüzen." Crucial 21st Century Cinema, 15 Eylül 2019. Erişim tarihi 24 Aralık 2019. https:/ / directedbywomen.com/crucial21dbw-motherland-ana-yurdu-directed-bysenem-tuzen $/$.

van Dijk, Teun A. 2005. "Söylemin Yapıları ve İktidar Yapıları." Çeviren Mehmet Küçük. Medya, İktidar, İdeoloji içinde, editör Mehmet Küçük, 321-24. Ankara: Bilim ve Sanat.

Wollen, Peter. 2010. “Godard ve Karşı Sinema: Doğu Rüzgârı.” Çeviren Ertan Yılaz. Sanat Sineması Üzerine Yaklaşımlar ve Tartışmalar içinde, editör Ali Karadoğan, 113-24. Ankara: De ki Basım Yayım Ltd. Şti. 